Ege Tıp Dergisi / Ege Journal of Medicine 2019; 58 (3): 200-207

\title{
Alkolik karaciğer hastalığı nedeniyle karaciğer nakli yapılan hastalarda psikiyatrik eş tanı ve yeniden alkol kullanımı: Bir ön çalışma
}

Psychiatric comorbidity and alcohol recidivism in patients who have undergone liver transplantation due to alcoholic liver disease: A preliminary study

\author{
Ürün Özer ${ }^{1}$ Ersin Uygun ${ }^{2}$ (D) \\ ${ }^{1}$ Acıbadem Üniversitesi Tıp Fakültesi, Psikiyatri Anabilim Dalı, İstanbul, Türkiye \\ ${ }^{2}$ Bakırköy Ruh Sağlığı ve Sinir Hastalıkları Hastanesi, Psikiyatri Kliniği, İstanbul, Türkiye
}

\section{Öz}

Amaç: Alkolik karaciğer hastalığı, karaciğer naklinin önde gelen endikasyonlarından biridir. Karaciğer nakli sonrasında olumlu sonuçlar elde edilmekle birlikte, bazı olgularda alkol alımının tekrar ortaya çıktığı bildirilmiştir. Çalışmamızın amacı bu hastalarda psikiyatrik eş tanıları ve karaciğer nakli sonrasındaki izlem döneminde yeniden alkol kullanımını incelemektir.

Gereç ve Yöntem: Kurumumuzda alkolik karaciğer hastalığı nedeniyle karaciğer nakli yapılan 14 hastanın bir yıllık tıbbi kayıtları retrospektif olarak incelenmiştir.

Bulgular: On dört hastadan beşinde $(\% 35,7)$ geçmişte psikiyatri başvurusu, dördünde $(\% 28,6)$ psikiyatrik tedavi öyküsü saptanmıştır. Psikiyatrik görüşme sırasında halen psikiyatrik hastalığı devam eden ve psikiyatrik tedavi gören hasta sayısı ikidir (\%14,3). Bu hastalarda gözlenen tanılar alkol kullanım bozukluğu, depresyon ve anksiyete bozukluğudur. İzlemde bir hasta kaybedilmiş, kalan 13 hastadan hiçbirinde alkol kullanımında yineleme gözlenmemiştir.

Sonuç: Alkolik karaciğer hastalığı karaciğer nakli için ideal bir endikasyondur ve yakın izlemle alkol kullanımında yineleme önlenebilir. Psikiyatri hem nakil öncesi hem nakil sonrası dönemde organ nakli ekibinin vazgeçilmez bir üyesi olmalıdır.

Anahtar Sözcükler: Karaciğer nakli, alkolik karaciğer hastalığı, alkol kullanım bozukluğu, yeniden alkol kullanımı

\section{Abstract}

Aim: Alcoholic liver disease is a leading indication for liver transplantation. Although the outcome after liver transplantation is favorable, a return to alcohol consumption is reported in some cases. The aim of this study is to examine psychiatric comorbidities and alcohol recidivism in these patients in follow-up after liver transplantation.

Materials and Methods: Medical records of 14 patients who have undergone liver transplantation due to alcoholic liver disease in our hospital were studied retrospectively.

Results: Five (35.7\%) among 14 patients had psychiatric admission and four patients (28.6\%) had history of psychiatric treatment. The number of patients who have current psychiatric disorder and receiving psychiatric treatment during psychiatric interview was two (14.3\%). Diagnoses of these patients were alcohol use disorder, depression and anxiety disorders. One patient died in the follow-up; no alcohol recidivism is seen in the remaining 13 patients.

Conclusion: Alcoholic liver disease is an excellent indication for liver transplantation and with close follow-up alcohol recidivism might be prevented. Psychiatry must be indispensable member of organ transplantation team, both in preoperational and postoperational periods.

Keywords: Liver transplantation, alcoholic liver disease, alcohol use disorder, alcohol recidivism.

\footnotetext{
Yazışma Adresi: Ersin Uygun

Bakırköy Ruh Sağlığı ve Sinir Hastalıkları Hastanesi, Psikiyatri

Kliniği, İstanbul, Türkiye

E-mail: ersinuygun@hotmail.com

Makalenin Geliş Tarihi: 20.05.2018 


\section{Giriş}

Karaciğer nakli, beyin ölümü gerçekleşmiş ya da sağlıklı insanlardan, normal işlevleri devam eden karaciğer dokusunun bir kısmının alınarak, karaciğer yetmezliği olan seçilmiş olgulardaki karaciğer dokusu ile değiştirilmesidir. Cerrahi teknikteki ve organ saklanmasındaki ilerlemeler, immünsüpresif tedavinin gelişmesi, verici ve alıcının seçimi ile nakil zamanının belirlenmesindeki gelişmeler sonucunda günümüzde karaciğer nakli sonrası yaşam oranları \%80'lere varmaktadır (1). Karaciğer nakli endikasyonları akut karaciğer yetmezliği, komplike olmuş siroz, bazı karaciğer neoplazmları ve sistemik bazı hastalıklara bağlı gelişen karaciğer bozuklukları olarak belirlenmiştir (2). Alkol kullanımına bağlı karaciğer hastalığı Avrupa ve Kuzey Amerika'da karaciğer naklinin en sık nedenleri arasında gösterilmektedir $(3,4)$. Çalışmalarda alkolik karaciğer hastalığı (AKH) nedeniyle karaciğer nakli yapılan hastalarda olumlu sonuçlar elde edildiği bildirilmiştir $(3,5)$.

Organ nakli öncesinde alıcının psikiyatrik değerlendirilmesi zorunlu olmamakla birlikte, önerilmektedir. Psikiyatrik değerlendirme sırasında, psikiyatrik muayenenin yapılması, psikiyatrik hastalık öyküsünün alınması, psikiyatrik hastalık öyküsü varsa belirtilerin, yineleme ve alevlenme açısından risk etkenlerinin değerlendirilmesi, tedavi uyumu ve sosyal desteğin yeterli olup olmadığının belirlenmesi, karar verme yetisinin, nakille ilgili beklentilerin ve nakle duygusal ve bilişsel açıdan hazır olup olmadığının ele alınması gerekmektedir. Ayrıca hastanın kullanmakta olduğu psikotrop ilaçlar ile nakil sonrasında verilecek ilaçların etkileşimlerinin değerlendirilmesi önemlidir (6). AKH nedeniyle karaciğer nakli planlanan hastalarda alkol kullanım öyküsünün alınması ve gerekli müdahaleler açısından psikiyatrik değerlendirme ayrıca önem taşımaktadır.

\section{Gereç ve Yöntem}

Çalışmamızda AKH nedeniyle karaciğer nakli olan hastalarda psikiyatrik eş tanıları saptamak ve bu hastaların 1 yıllık izleminde alkol kullanımında yineleme oranını belirlemek amaçlanmıştır. Bu nedenle 1 Haziran 2016 - 1 Aralık 2016 tarihleri arasında kurumumuzda AKH nedeniyle karaciğer nakli operasyonu yapılan hastaların bir yıllık tıbbi kayıtları retrospektif olarak incelendi. Kurumumuzda tüm organ nakli operasyonları öncesi alıcı ve vericiler psikiyatrist tarafından değerlendirilmektedir. Bu olgulara yapılandırılmış psikiyatrik muayene yapılmakta, detaylı öykü alınmakta ve rapor düzenlenmektedir. AKH'ye bağlı karaciğer nakli planlanan hastalarda ayrıca alkol kullanımının değerlendirilmesi açısından rutin olarak yapılan tıbbi tetkiklere ek olarak idrarda madde metaboliti taraması istenmektedir.

Kurumumuzda karaciğer yetmezliği olan hastalarda karaciğer nakli endikasyonu ve bekleme listesi Model for End-stage Liver Disease (MELD) skorlamasına göre belirlenmektedir.

\section{Bulgular}

Belirtilen zaman aralığında kurumumuzda AKH'ye bağlı karaciğer nakli yapılan olgu sayısı 14 olarak belirlendi. Hastaların yaş ortalaması $54,4 \pm 6,5$ ve yaş aralığı 47-66 yıldı. Tamamı erkekti. Öğrenim durumu ele alındığında, 1 hasta $(\% 7,1)$ hiç okula gitmemiş, 7 hasta (\%50) ilköğretim mezunu, 4 hasta $(\% 28,6)$ lise mezunu, 2 hasta $(\% 14,3)$ üniversite mezunu idi. On üç hasta $(\% 92,9)$ evli, 1 hasta $(\% 7,1)$ boşanmıştı, hastaların tümü çocuk sahibi olup tamamının ailesiyle birlikte yaşadığı öğrenildi. Dokuz hasta $(\% 64,3)$ çalışmıyorken, 5 hasta $(\% 35,7)$ halen çalıştığını belirtti.

Psikiyatrik öykü incelendiğinde, 9 hastanın $(\% 64,3)$ daha önce psikiyatri başvurusu olmamışken, 5 hasta $(\% 35,7)$ daha önce psikiyatriye yardım alma amaçlı başvurduğunu bildirdi. On hasta $(\% 71,4)$ daha önce psikiyatrik tedavi almadığını belirtirken, 4 hasta $(\% 28,6)$ daha önce tedavi amaçlı psikotrop ilaç kullandığını ifade etti. Psikiyatrik görüşme sırasında halen psikiyatrik hastalığı devam eden ve bu nedenle psikiyatrik tedavi gören hasta sayısı 2 $(\% 14,3)$ olarak belirlendi. Sadece 2 hastanın $(\% 14,3)$ geçmişte alkol kullanım bozukluğu tanısı aldığı ve bu nedenle psikiyatrik tedavi gördüğü öğrenildi. Diğer psikiyatrik tanısı olan hastalardan ikisinde $(\% 14,3)$ depresyon, birinde $(\% 7,1)$ anksiyete bozukluğu öyküsü belirtildi. Halen psikiyatrik hastalığı devam eden ve bu nedenle psikiyatrik tedavi gören hastalardan ise biri $(\% 7,1)$ depresyon, biri $(\% 7,1)$ anksiyete bozukluğu nedeniyle tedavi görmekte idi.

Alkol kullanımı detaylandırıldığında, toplam alkol kullanım süresi ortalama $23 \pm 10,9$ yıl olup, aralığı 345 yıl olarak belirlendi. Alkolü bırakma süresi ortalama $14 \pm 15,1$ ay olup, aralığı 3-60 ay arasında idi. Tüm hastaların alkolü bıraktıktan en az 6 ay sonra karaciğer nakli operasyonuna alındığı, sadece 1 hastada alkol kullanımı bırakma süresinin 3 ay olduğu saptandı. 
On hastada $(\% 71,4)$ halen sigara kullanımı saptandı, 4 hasta $(\% 28,4)$ sigara kullanmadığını belirtti. Hastaların hiçbirinde psikoaktif madde kullanımı tarif edilmedi.

Hastaların 8'inde $(\% 57,1)$ eş tanılı genel tıbbi hastalıkların varlığı saptandı, 6'sında $(\% 42,9)$ eşlik eden bir genel tıbbi hastalık bulunamadı. Genel tıbbi hastalıklar arasında en sık olarak hipertansiyon (5 hasta) ve diabetes mellitus (3 hasta) yer almakta idi. Hastaların 3'ünde $(\% 21,4)$ eş tanılı nörolojik hastalık varlığı saptandı, 11 hastada $(\% 78,6)$ eşlik eden nörolojik hastalık bulunamadı, 2 hastada $(\% 14,3)$ hepatik ensefalopati öyküsü vardı. Hastalardan 1'inde ise eş tanılı hepatit $C$ tanısı saptandı.

Hastalardan 11'inde $(\% 78,6)$ karaciğer dokusu canlı vericiden alınmışken, 3 hastada $(\% 21,4)$ kadavradan alınmıştı. Vericilerden 3'ü hastanın akrabası olmayan kişiler iken, 6'sı hastanın akrabası olup, 2 hastada eşi, 2 hastada kardeşi, 2 hastada oğlu, 1 hastada kızı, 1 hastada ise gelini verici olmuştu.

Karaciğer nakli sonrası 1 yıllık izlem döneminde 12 hastada $(\% 85,7)$ komplikasyon geliştiği gözlendi. Hastalardan 1'i $(\% 7,1)$ hepatik arterde tromboz ortaya çıkması nedeniyle postoperatif dönemde eksitus ile sonuçlandı. Hastalarda gözlenen komplikasyonlar Tablo-1'de özetlenmiştir. Hiçbir hastada alkol kullanımında yineleme gözlenmedi.

Tablo-1. Karaciğer Nakli Sonrası İzlemde Gözlenen Kompliklasyonlar.

\begin{tabular}{ll}
\hline Komplikasyon & $\mathbf{n}$ \\
\hline Ateş & 4 \\
KCFT yüksekliği & 5 \\
Pnömoni & 2 \\
Bronşit & 1 \\
Pnömotoraks & 1 \\
GIS kanama & 1 \\
Dispepsi & 2 \\
Safra yolu obstrüksyonu & 3 \\
Kolanjit & 1 \\
Göğüs ağrısı & 1 \\
Nefes darlığı & 1 \\
Diş apsesi & 1 \\
Üriner sistem enfeksiyonu & 1 \\
Sepsis & 1 \\
Hematom & 1 \\
Umbilikal herni & 1 \\
Tromboz & 1 (Eksitus) \\
\hline
\end{tabular}

\section{Tartışma}

Karaciğer sirozu olan hastalarda MELD skorlamas değerlendirilerek nakil kararı alınmaktadır. MELD skorunun 15 'in üzerinde olması durumunda hastalar nakil için potansiyel birer aday kabul edilirken, MELD skoru 10'u geçen hastalar nakil için değerlendirme sürecine alınmaktadır (2). Kurumumuzda nakil sırası MELD skoruna göre belirlenmektedir. Yazında AKH karaciğer naklinin önde gelen nedenleri arasında gösterilmekle birlikte, bazı olgularda bu tanıya eşlik eden viral hastalıklar ve diğer karaciğer hastalıklarına da rastlanmaktadır $(3,7)$. Çalışmamızda yalnızca bir olgu AKH'ye ek olarak viral hepatit (hepatit C) tanısı almıştır.

Alkol kullanımının halen devam ediyor olması genel olarak karaciğer nakli için kontrendikasyon (kesin ya da rölatif) olarak kabul edilmektedir (8). $\mathrm{AKH}$ olan olgularda nakil öncesi en az 6 ay alkol kullanımının olmaması birçok merkez tarafından gereklilik olarak belirlenmiştir $(2,8,9)$. Ancak, 3 ay ya da 12 ay süreyle alkol kullanımının olmaması koşulunu arayan merkezler de bildirilmiştir (8). Bazı olgularda tıbbi durumun ciddiyeti ve hayati risk dolayısıyla bu süreler beklenmeyebilmektedir (10). Ayrıca hastaların alkol bırakma rehabilitasyon programına katılmış olmaları ve yeterli aile desteğinin varlığı da bazı çalışmacılar tarafından gerekli görülmektedir $(2,8,10)$. Bazı merkezlerin karaciğer nakil listesine aldıkları hastalarda alkol kullanımının ortaya çıkması durumunda, bu hastaları listeden çıkardıkları bildirilmiştir. Bazı merkezler ise bu hastaları bir süre sonra (2 ay ila 2 yıl arasında) tekrar değerlendirerek alkol kullanımının olmaması durumunda yeniden listeye almaktadır (8). Kurumumuzda karaciğer nakli operasyonu yapılacak hastalarda 6 ay alkol kullanmama koşulu aranmaktadır. Çalışmamızda yalnızca 1 olguda genel tıbbi durumun kötüleşmesi nedeniyle 6 aydan kısa süren ayıklık dönemi sonrasında karaciğer nakli yapılmıştır. Bekleme listesine alınan karaciğer nakli adayı hastaları, alkol alımı ortaya çıktığında pasif konuma getirilmekte, 3 ay kullanmadığından emin olunduktan sonra tekrar aktif hale aktif hale getirilmektedir.

Karaciğer nakli öncesi değerlendirmede yapılması gereken tetkik ve işlemler arasında AB0-Rh kan grubunun belirlenmesi, karaciğer biyokimyasal ve işlevsel testleri, tam kan sayımı, böbrek fonksiyon 
testleri ve kreatinin klirensinin hesaplanması, serum alfa fetoprotein düzeyinin ölçülmesi, kalsiyum ve vitamin $D$ düzeylerinin ölçülmesi, sitomegalovirüs (CMV), Epstein-Barr virüs (EBV), human immunodefficiency virüs (HIV), Hepatit A, B ve $C$ virüsleri serolojileri, idrar incelemesi, elektrokardiyogram (EKG), eforlu EKG, oksimetri, kanser taraması, enfeksiyöz hastalık taraması (pnömokok, influenza, difteri, pertussis ve tetanoz) ve aşılama, hepatik görüntüleme ve hepatoselüler karsinom evrelemesi, üst gastrointestinal sistem (GiS) endoskopisi, kemik dansitometrisi yer almaktadır. Birçok branşın değerlendirmesine ek olarak psikiyatri muayenesi ve idrarda madde metaboliti taraması da yapılmaktadır (2). Kurumumuzda karaciğer nakli öncesi yapılan tetkik ve işlemler Tablo-2'de verilmiştir. Everhart ve Beresford (8) çalışmalarında karaciğer nakli yapılan 68 merkez incelenmiş ve bu merkezlerin çoğunda (\%83) AKH olan ve karaciğer nakli planlanan tüm hastaların psikiyatrist ya da bağımlılık uzmanı tarafından rutin olarak muayene edildiği bildirmişlerdir. Bazı merkezlerde ise psikiyatrist listeye dahil etme kararına aktif olarak katılmakta ya da alkol kullanım bozukluğunu tedavi etme görevini üstlenmektedir (8). Ülkemizde karaciğer nakli öncesi alıcının psikiyatrik muayenesinin yapılması şart koşulmamıştır. Kurumumuzda karaciğer nakli öncesi mutlaka psikiyatrist tarafından psikiyatrik değerlendirme yapılmakta ve devam eden alkol kullanımını dışlamak amacıyla idrarda madde metaboliti bakılmaktadır. Ayrıca karaciğer nakli planlanan hastanın değerlendirilmesinde yukarıda belirtilen tıbbi işlemler uygulanmaktadır.

Karaciğer nakli sonrası gelişebilecek medikal sorunlar nedeniyle hastaların yakın takip edilmesi önerilmektedir. Bu sorunlar akut ve kronik rejeksiyon, immünsüpresif tedavinin komplikasyonları, biliyer komplikasyonlar ve primer karaciğer hastalığın rekürrensi olarak sıralanmaktadır (2). Kurumumuzda karaciğer nakli sonrası hastalar yakın izlenmektedir. Karaciğer nakli operasyonu sonrası 1 gece yoğun bakım ünitesinde olmak üzere, ortalama 12-15 gün hastanede kaldıktan sonra taburcu edilmektedir. İlk 3 ay 15 günde bir (safra direni varsa haftada bir), 3 aydan sonra ayda bir, 1 yıldan sonra ise ömür boyu yılda bir sorumlu hekim tarafından ilgili tetkikler ile detaylı değerlendirilmektedir.
Tablo-2. Karaciğer Nakli Öncesi Yapılan Tetkik ve İşlemler.

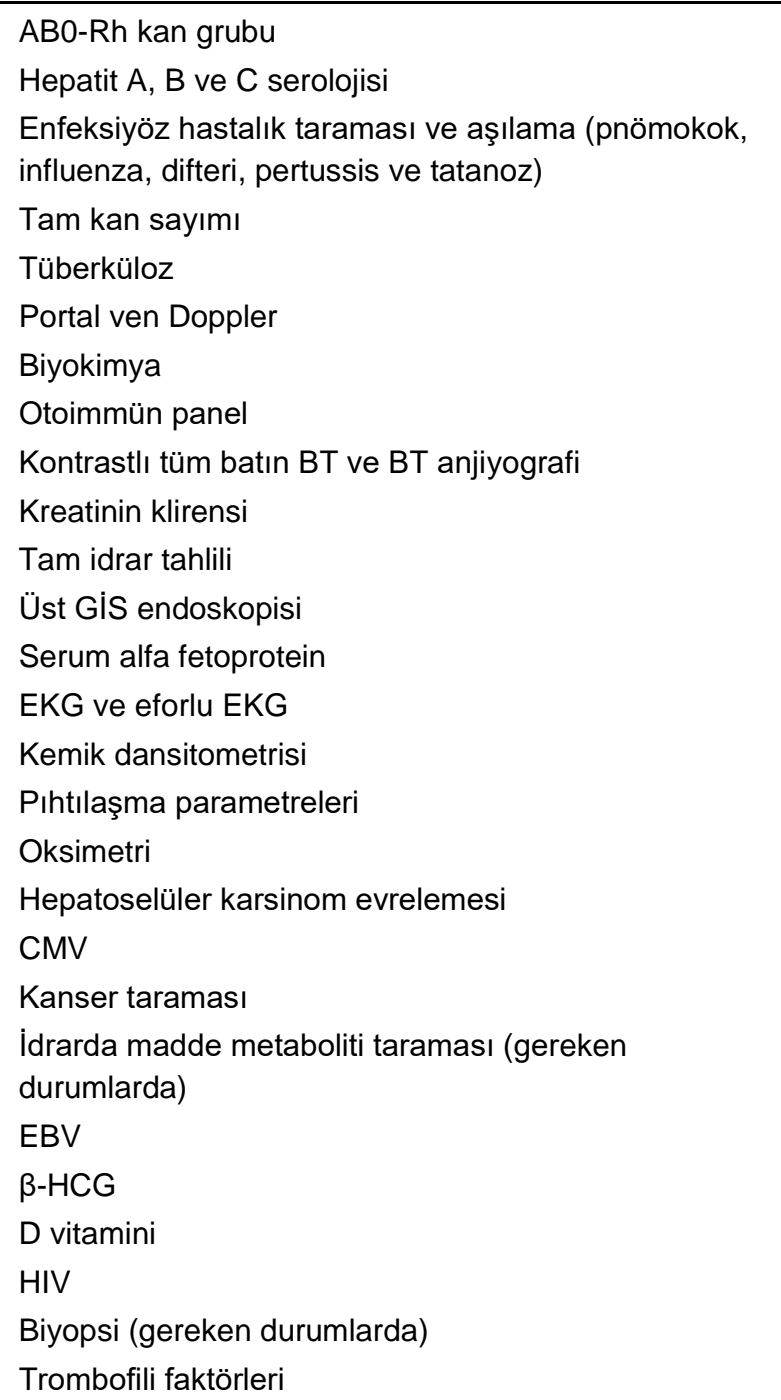

Burra ve ark. (3) çalışmasında AKH nedeniyle karaciğer nakli olan hastaların izleminde de novo tümörler, lenfoproliferatif hastalıklar, enfeksiyonlar, kardiyovasküler nedenler ve rejeksiyon en sık gözlenen greft başarısızlığı ve ölüm nedenleri arasında yer almaktadır. Diğer bir çalışmada karaciğer nakli sonrası en sık ölüm nedenleri arasında malign tümörler, enfeksiyonlar, kardiyovasküler hastalıklar sıralanmıştır (11). Bellamy ve ark. (7) da AKH nedeniyle karaciğer nakli olan hastalarda de novo tümörlerin (özellikle üst solunum ve sindirim sistemi skuamöz hücre karsinomları) sık gözlendiğini belirtmiştir. Biliyer komplikasyonlar ile biyopsi sırasında gelişen safra kanalı hasarı ve periselüler fibroz da greft 
başarısızlığının öngörücüleri arasında bulunmuştur. Çalışmamızda 14 hastadan yalnızca biri postoperatif dönemde gelişen tromboza bağlı olarak kaybedilmiştir.

Çalışmalarda karaciğer nakli yapılan hastalardan, nakil sonrası süreçte hiç alkol almamalarının istendiği belirtilmektedir $(8,11)$. Kurumumuzda karaciğer nakli geçiren hastalara detaylı bilgilendirme yapılarak nakil sonrası hiç alkol kullanmamaları önerilmektedir.

Çalışmalarda karaciğer nakli yapılan hastalarda izlemde alkol kullanımının, hastalar ve hasta yakınlarıyla yapılan görüşmeler, hastayı izleyen birinci basamak hekiminin görüşleri, kan ve idrar testleri yoluyla saptandığı not edilmiştir, nadiren greftten biyopsi de alınabilmektedir $(5,8,11)$. Kurumumuzda da karaciğer nakli yapılan hastaların izleminde alkol kullanımı aynı yöntemlerle belirlenmektedir.

Karaciğer nakli sonrası alkol kullanım oranları çalışmalar arasında farklılık göstermekte olup $\mathrm{AKH}$ nedeniyle nakil olan hastalarda izlemde \%19-95 arasında değişen oranlarda alkol kullanımında yineleme bildirilmiştir $(3,5,11,12,13,14)$. Burra ve ark. (15) hastaların \%33'ünde alkol kullanımının yinelediği belirlenmiştir. Bunlardan \%64'ünde alkol kullanımı ara sıra iken, \%36'sında yoğun alkol kullanımı (haftada 200 gramdan fazla) saptanmıştır. Diğer çalışmalarda karaciğer nakli sonrası ilk 1 yılda alkol kullanım oranları \%11 ve \%22 olarak saptanmıştır $(10,14)$. Pageaux ve ark. (5) çalışmasında da alkol kullanımında yineleme gözlenen hastalardan \%22,5'inin nakil sonrası ilk bir yılda alkol kullanmaya başladığı belirlenmiştir. Bazı çalışmalarda ise AKH ve diğer nedenlerle karaciğer nakli olan hastaları karşılaştırılmış, bu iki grup arasında nakil sonrasında alkol kullanım oranları açısından anlamlı bir fark olmadığı bildirilmiştir $(16,17)$.

Nakil öncesi ayıklık süresinin 6 aydan kısa olması, işsizlik, yalnız yaşama, genç yaş, küçük yaşta çocukların varlığı alkol kullanımının yinelemesi ile ilişkili bulunmuştur $(5,9,11,14)$. Bazı çalışmalarda günlük alkol tüketimi miktarının fazlalığı, alkol kullanım bozukluğuna yönelik iç görünün olmayışı ve daha önce başarısız bırakma girişimlerinin varlığı alkol kullanımı ile ilişkili etkenler olarak öne çıkmıştır $(7,9)$. DiMartini ve ark. (10) çalışmasında depresif bozukluk öyküsü nakil sonrası alkol kullanımı açısından risk etkeni olarak belirtilmiştir.
Nakil sonrasında alkol alınmayan süre uzadıkça, alkol alımının yinelemesi olasılığının azaldığı saptanmıştır. Alkol kullanımının yinelemesi açısından risk etkenleri Şekil-1'de gösterilmiştir. Çalışmamızda 14 hastadan $1^{\prime} i$ postoperatif dönemde kaybedilmiş olup, diğer hastaların hiçbirinde izlemde alkol kullanımında yineleme olmaması dikkat çekicidir. Bu nedenle çalışmamızda alkol kullanımının yinelemesi ile ilişkili olabilecek değişkenleri incelemek mümkün olmamıştır.

Burra ve ark. (3) çalışmasında alkole bağlı karaciğer hastalığı nedeniyle karaciğer nakli yapılan hastalarda sağ kalım oranlarının, viral ya da kriptojenik siroz nedeniyle karaciğer nakli yapılan hastalara göre daha iyi olduğu saptanmıştır. Bellamy ve ark. (7) AKH nedeniyle karaciğer nakli yapılan hastalarda sağ kalım oranlarını 1 yıl, 5 yıl ve 7 yıl için sırasıyla \%84, $\% 72$ ve $\% 63$ olarak belirlemişlerdir. Çalışmamızda AKH'de karaciğer nakli sonrası uzun dönemli sağ kalım oranı hakkında bilgi edinilememekle birlikte, 1 yıllık izlemde sağ kalım oranının çok yüksek olduğu görülmektedir (\%92,9).

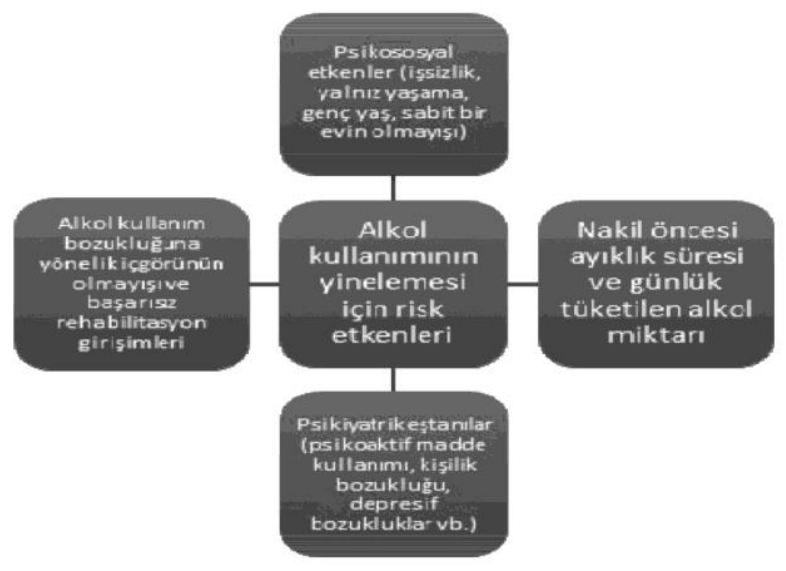

Şekil-1. AKH'de karaciğer nakli sonrası alkol kullanımının yinelemesi için risk etkenleri.

Burra ve ark. (3) çalışmasında alkole bağlı karaciğer hastalığı nedeniyle karaciğer nakli yapılan hastalarda sağ kalım oranlarının, viral ya da kriptojenik siroz nedeniyle karaciğer nakli yapılan hastalara göre daha iyi olduğu saptanmıştır. Bellamy ve ark. (7) AKH nedeniyle karaciğer nakli yapılan hastalarda sağ kalım oranlarını 1 yıl, 5 yıl ve 7 yıl için sırasıyla $\% 84$, $\% 72$ ve $\% 63$ olarak belirlemişlerdir. Çalışmamızda 
AKH'de karaciğer nakli sonrası uzun dönemli sağ kalım oranı hakkında bilgi edinilememekle birlikte, 1 yıllık izlemde sağ kalım oranının çok yüksek olduğu görülmektedir $(\% 92,9)$.

Yazında karaciğer nakli sonrası alkol kullanımının sağ kalım üzerinde etkisi üzerine çelişen bulgulara rastlanmaktadır. Alkol kullanımı yineleyen hastalarda greftte yalnızca minör histolojik değişiklikler meydana geldiği (15), ya da alkol kullanımının nadiren greft başarısızlığına ya da ölüme yol açtığını bildiren $(3,12)$ çalışmalar olmakla birlikte nakil sonrası yoğun alkol alan hastalarda sağ kalım oranlarının, alkol almayanlara göre daha düşük olduğunu bildiren çalışmalar da mevcuttur (11). Bazı çalışmalarda ise alkol kullanımının yinelediği hastalarda erken dönemde sağ kalım oranları değişmezken, uzun dönemde (10 yıl) sağ kalımın azaldığı vurgulanmıştır (12). Pfitzmann ve ark. (11), karaciğer nakli sonrası yoğun miktarda alkol kullanan hastalarda yeniden gelişen AKH'nin ölüm nedenlerinin başında geldiğini saptamıştır. Bellamy ve ark. (7) ise karaciğer nakli geçiren 123 hastadan, nakil sonrasında alkol kullanımında yineleme gözlenen 13 hastanın hiçbirinde alkole bağlı hepatit ya da rejeksiyon gözlememiştir. Alkol kullanımının yinelediği hastalarda greftte gözlenebilen hasarın, bu hastalarda immünosüpresif tedaviye uyumsuzluğun eşlik etmesinden kaynaklandığı da ileri sürülmektedir $(5,12)$. Yine alkol kullanımında yineleme gözlenen hastalarda uzun dönemde azalan sağ kalım oranları eşlik eden diğer hastalıklar (kanser ve kardiyovasküler hastalıklar) ile açıklanabilmektedir (12). Alkol kullanımı yineleyen hastalarda aynı zamanda sigara kullanımının da fazla olduğunu gösteren çalışmalar mevcuttur $(5,12)$. Dolayısıyla alkol kullanımında yineleme gözlenen hastalarda immünsüpresif ve diğer tedavilere uyumun dikkatle değerlendirilmesi ve eşlik edebilecek diğer hastalıkların ve sigara kullanımının araştırılması da önem taşımaktadır.

Çalışmalarda halen bazı klinisyenlerin $\mathrm{AKH}$ nedeniyle karaciğer nakli yapılmasının gerekliliğini sorguladıklarının altı çizilmiştir. Hatta bazı çalışmalarda AKH'de karaciğer nakli oranlarının diğer karaciğer hastalıklarına kıyasla daha düşük olduğu bildirilmiştir $(18,19)$. Bunun altında bu hastaların hastalıklarından "kendilerinin sorumlu" olduğu, karaciğer naklini "başkalarından daha az hak ettiği” düşüncesi, hastaların karaciğer nakli sonrası yeniden alkol kullanmaya başlayacakları endişesi ve psikiyatrik ve sosyal sorunlar nedeniyle kompliyansın kötü olacağı görüşü yatmaktadır $(3,4,14)$. Oysa ki, çalışmalarda karaciğer nakli sonrası alkol kullanım oranlarının düşüklüğü, olsa dahi greft başarısını etkilemediği ve diğer nakil nedenlerine göre iyi sağ kalım oranlarının olduğu bildirilmiştir $(7,12)$.

Yazında AKH tanılı hastalarda eş tanılı psikiyatrik bozuklukların (kişilik bozuklukları, duygu durum bozuklukları, ya da psikotik bozukluklar vb.) ve psikoaktif madde kullanımının karaciğer nakli kararında önem taşıdığı bildirilmiştir. DiMartini ve ark. (10) çalışmasında AKH nedeniyle karaciğer nakli olmuş hastaların \%40'ında psikoaktif madde kullanım öyküsü alınmıştır. Aktif psikotik bozukluk ve aktif psikoaktif madde kullanımı karaciğer nakli açısından kontrendikasyon oluşturmaktadır (8). Kuşkusuz karaciğer nakli sonrasında da bu hastalarda çeşitli psikiyatrik bozukluklar görülebilmektedir. Çalışmalarda $\mathrm{AKH}$ nedeniyle karaciğer nakli geçiren olguların birçoğunda depresif bozukluk öyküsü olduğu, hatta çalışma bir olgunun intihar nedeniyle hayatını kaybettiği not edilmiştir $(5,10)$. Çalışmamızda da hem geçmişte psikiyatrik hastalık öyküsü olan, hem de halen psikiyatrik hastalığı devam eden hastalara rastlanmıştır. Örneklemde gözlenen psikiyatrik hastalıklar yazınla uyumlu olarak depresyon ve anksiyete bozukluğudur. Ayrıca çok az sayıda hastanın geçmişte alkol kullanım bozukluğu tanısı aldığı ve psikiyatrik tedavi gördüğü anlaşılmıştır. Bu bulgu bu hasta grubunda erken dönemde tanı konmasının ve tedavi önerilmesinin ilerleyen yıllarda ortaya çıkacak bir karaciğer yetmezliği önlemede etkili olabileceği sonucunu düşündürmektedir.

AKH nedeniyle karaciğer nakli olan hastalarda sağlam bir hasta-hekim ilişkisinin geliştirilmesinin ve uzun dönem yakın izlemin bu hastalarda alkol kullanımının yinelemesini azalttığı ve yineleme olduğunda bunun erkenden belirlenmesini sağladığı bildirilmiştir (12). Aynı zamanda nakil sonrasında psikososyal destek alan hastalarda yinelemenin daha az oranda gözlendiğinin de altı çizilmiştir (5).

Çalışmamı AKH nedeniyle karaciğer nakli olan olgularda psikiyatrik eş tanıları ve alkol kullanımında yineleme oranını araştıran, bilgimiz 
dahilinde Türkiye'de yapılan ilk çalışma olma özelliğini taşımaktadır. Psikiyatrik değerlendirmenin kendi bildirim testleri ile sınırlı kalmayıp, bir psikiyatrist tarafından yapılandırılmış muayene ile yapılması ve idrarda madde metaboliti testleri ile desteklenmesi çalışmanın güçlü yönlerini oluşturmaktadır. Çalışmamızın kısıtıııkları; tek bir kurumda yürütülmüş olması ve bu nedenle örneklem sayısının azlığıdır. Ek olarak, hiçbir hastada alkol alımında yineleme gözlenmemesi nedeniyle, bununla ilişkili olabilecek değişkenleri araştırmak mümkün olamamıştır. İzlem süresinin 1 yılla sınırlı kalmış olması da diğer bir kısıtlılıktır, izlem süresini uzatarak uzun dönem sağ kalım hakkında bilgi verecek çalışmalara intiyaç bulunmaktadır.

\section{Sonuç}

Karaciğer nakli sonrası alkol kullanımı değişen oranlarda yineleyebilmekle birlikte, AKH hastalarında karaciğer naklinin başarı ve sağ kalım oranlarının yüksek olduğu ve alkol kullanımının greft başarısı ve sağ kalım üzerinde ancak kısmi etkisinin bulunduğu düşünüldüğünde bu hastalarda karaciğer nakli etkin bir tedavi yöntemi olarak öne çıkmaktadır. Psikiyatrinin hem karaciğer nakli öncesinde hasta seçimindeki rolü, hem de karaciğer nakli sonrasında destek sağlamak açısından yeri düşünüldüğünde, psikiyatristlerin organ nakli ekiplerinin vazgeçilmez birer üyesi olması gerektiği sonucu çıkmaktadır. Özellikle AKH olgularında hem nakil öncesi hem nakil sonrası dönemde psikiyatrinin rolü daha da önem kazanmaktadır.

\section{Teşekkür}

Organ nakli merkezi sorumlusu Prof. Dr. Remzi Emiroğlu ve karaciğer nakli merkezi koordinatörü Meral Palta'ya teşekkür ederiz.

\section{Kaynaklar}

1. Kasapoğlu B, Yalçın KS, Türkay C. Canlı donörden karaciğer transplantasyonu. Güncel Gastroenteroloji 2010; 14 (2): 96-102.

2. Taşkıran E, Akar H, Yıldııı M, Erbaş O. Karaciğer nakli: Endikasyonlar, kontrendikasyonlar, rejeksiyon ve uzun dönem takip. FNG\&Bilim Tıp Transplantasyon Dergisi 2016; 1 (2): 59-66.

3. Burra $P$, Senzolo M, Adam R, et al. Liver transplantation for alcoholic liver disease in Europe: A study from ELTR (European Liver Transplant Registry). Am J Transplant 2010; 10 (1): 138-48.

4. Perut $\mathrm{V}$, Conti $\mathrm{F}$, Scatton $\mathrm{O}$, et al. Might physicians be restricting access to liver transplantation for patients with alcoholic liver disease? J Hepatol 2009; 51 (4): 707-14.

5. Pageaux GP, Bismuth M, Perney $\mathrm{P}$, et al. Alcohol relapse after liver transplantation for alcoholic liver disease: Does it matter? J Hepatol 2003; 38 (5): 629-34.

6. Özçürümez G, Tanrıverdi N, Zileli L. Böbrek transplantasyonu ve psikiyatri. Klinik Psikiyatri 2003; 6 (4): 225-34.

7. Bellamy COC, DiMartini AM, Ruppert K, et al. Liver transplantation for alcoholic cirrhosis: Long term follow-up and impact of disease recurrence. Transplantation 2001; 72 (4): 619-26.

8. Everhart JE, Beresford TP. Liver transplantation for alcoholic liver disease: A survey of transplantation programs in the United States. Liver Transpl Surg 1997; 3 (3): 220-6.

9. Dureja P, Lucey MR. The place of liver transplantation in the treatment of severe alcoholic hepatitis. J Hepatol 2010; 52 (5): 759-64.

10. DiMartini A, Day N, Dew MA, et al. Alcohol consumption patterns and predictors of use following liver transplantation for alcoholic liver disease. Liver Transpl 2006; 12 (5): 813-20.

11. Pfitzmann R, Schwenzer J, Rayes N, et al. Long-term survival and predictors of relapse after orthotopic liver transplantation for alcoholic liver disease. Liver Transpl 2007; 13 (2): 197-205.

12. Cuadrado A, Fabrega E, Casafont $F$, Pons-Romero $F$. Alcohol recidivism impairs long-term patient survival after orthotopic liver transplantation for alcoholic liver disease. Liver Transpl 2005; 11 (4): 420-46. 
13. Berlakovich GA, Steininger R, Herbst $F$, et al. Efficacy of liver transplantation for alcoholic cirrhosis with respect to recidivism and compliance. Transplantation 1994; 58 (5): 560-5.

14. Miguet M, Monnet E, Vanlemmens $C$, et al. Predictive factors of alcohol relapse after orthotopic liver transplantation for alcoholic liver disease. Gastroenterol Clin Biol 2004; 28 (10): 845-51.

15. Burra $P$, Mioni D, Cillo $U$, et al. Long-term medical and psychosocial evaluation of patients undergoing orthotopic liver transplantation for alcoholic liver disease. Transplant Int 2000; 13 (1): 174-8.

16. Bravata DM, Olkin I, Barnato AE, et al. Employment and alcohol use after liver transplantation for alcoholic and nonalcoholic liver disease: A systematic review. Liver Transplant $2001 ; 7$ (3): 191-203.

17. Mackie J, Groves K, Hoyle A, et al. Orthotopic liver transplantation for alcoholic liver disease: A restrospective analysis of survival, recidivism, and risk factors predisposing to recidivism. Liver Transpl 2001; 7 (5): 418-27.

18. Julapalli VR, Kramer JR, El Serag HB. Evaluation for liver transplantation: Adherence to AASLD referral guidelines in a large veterans affairs center. Liver Tranpl 2005; 11 (11): 1370-8.

19. Tuttle-Newhall JE, Rutledge R, Johnson M, Fair J. A statewide, population-based time series analysis of access to liver transplantation. Transplantation 1997; 63 (2): 255-62. 